\title{
The isotopic differences and implications for Pacific razor clams along the Washington coast
}

\author{
Yongwen $\mathrm{Gao}^{1, *}$, Joseph Gilbertson ${ }^{2}$, and Hongyan Zhang ${ }^{3}$ \\ ${ }^{1}$ Makah Fisheries Management, P.O. Box 115, Neah Bay, WA 98357, USA \\ ${ }^{2}$ Hoh Natural Resources Department, P.O. Box 2196, Forks, WA 98331, USA \\ ${ }^{3}$ School of Environment \& Sustainability, University of Michigan, Ann Arbor, MI 48108, USA
}

\begin{abstract}
The Pacific razor clam fishery in Washington State has been co-managed by the coastal Indian Tribes and the state, but little is known about the growth and population structure of the clams due to difficulties of tagging and monitoring. Here we report the results of a pilot study using stable isotope ratios $\left(\delta^{13} \mathrm{C}\right.$ and $\left.\delta^{18} \mathrm{O}\right)$ of razor clam shells collected in two groups (juvenile vs. adult) and from two sites (Kalaloch Beach and Roosevelt Beach) where distinct biological differences in clam growth and survival rates were observed. The $\delta^{13} \mathrm{C}$ values of razor clam shells ranged from -2.9 to $-0.3 \%$, whereas $\delta^{18} \mathrm{O}$ values of the same samples ranged from -2.2 to $+1.4 \%$. Between the two sites there were significant differences in $\delta^{13} \mathrm{C}$ values especially for juvenile clams. The $\delta^{18} \mathrm{O}$ profiles from two representative shells demonstrated similar patterns of rapid growth as juveniles and seasonal patterns throughout the life span. Profiles of $\delta^{13} \mathrm{C}$ were sinusoidal but did not show seasonality and signatures of ocean acidification. We concluded that stable isotope analysis of razor clam shells is a potential new tool in shellfish research and management.
\end{abstract}

\section{Introduction}

Pacific razor clam, Siliqua patula (Dixon, 1789), is an important shellfish species distributed along the United States west coast from Pismo Beach in southern California to the Aleutian Islands in Alaska [1]. It is abundant on beaches along the open coast of Washington State [2] and is well adapted to living in wave exposed sandy substrates. Razor clams are the most important and popular shellfish eaten by the indigenous people of the Hoh and Quinault tribes and is widely fished by recreational harvesters on other beaches in Washington and northern Oregon. In Washington State, there are five Pacific razor clam management areas in the recreational fishery: Long Beach, Twin Harbors, Copalis, Mocrocks, and Kalaloch. Joint population assessments are conducted annually to determine the total allowable catches (TACs). The TACs are set by applying a variable harvest rate to the total number of clams over $7.6 \mathrm{~cm}$, and are divided by agreement between the Washington Department of Fish and Wildlife (WDFW) and the coastal Indian Tribe comanagers. Fishing seasons are determined and each management group monitors its own

\footnotetext{
* Corresponding author: gaoy@olypen.com
} 
fishery. However, differences have been observed between Kalaloch Beach and the south adjacent Roosevelt Beach with respect to "harvestable" adult clam density and young of year clam density in recent years (WDFW, Hoh, and Quinault, unpublished management data). These differences resulted in diminished harvest that reduced harvest opportunity at Kalaloch Beach and had negative impacts on tribal member's ability to exercise reserved Treaty-rights for shellfish and recreational opportunities for non-tribal harvesters. Several hypotheses have been proposed for these differences, such as clam foraging conditions, disease, water temperature, and climate related ocean acidification in the changing beach environment [3]. To the authors' knowledge, no studies have tested these hypotheses and little is known about the population structure of razor clams due to difficulties to implement "tag and recover" programs [1] in the field.

The geochemical approach can provide a wealth of information about the environment in which the organisms lived as well as about their life histories [4]. The razor clam shell, with a heavy, glossy, yellowish periostracum skin [5], is mainly composed of calcium carbonate $\left(\mathrm{CaCO}_{3}\right)$. The use of stable isotope ratios in biogenic carbonate is well established as a proxy for reconstruction of water temperatures in ocean settings [6]. In general, a "vital effect" or biologically induced disequilibrium fractionation is not the rule, such that ${ }^{18} \mathrm{O} /{ }^{16} \mathrm{O}$ measures can be reliably used as proxies of water temperature. The carbon isotope ratios $\left({ }^{13} \mathrm{C} /{ }^{12} \mathrm{C}\right)$ of shell carbonate do not reach equilibrium conditions, but they can reflect metabolic status of the marine organism and may show trophic level changes in forage base as the animal grows $[7,8]$.

In this paper, we report stable isotope analyses $\left(\delta^{13} \mathrm{C}\right.$ and $\left.\delta^{18} \mathrm{O}\right)$ on Pacific razor clam shells from two sites (Kalaloch Beach and Roosevelt Beach) and in two groups (juvenile vs. adult clams) collected at a similar time. The primary objective of the project was to determine whether there were significant isotopic differences between the Kalaloch Beach and the Roosevelt Beach samples due to different growth and survival rates from biological observations. The second goal of the research was to use stable isotope profiles from representative razor clam shells as a record of aging and growth and detect if there were possible isotopic signatures on ocean acidification. Overall, we hope to use the isotopic technique to obtain geochemical information about the factors influencing the growth and survival of the Pacific razor clams.

\section{Materials and Methods}

Pacific razor clam shells were collected from two sites, the Hoh Tribe's traditional harvesting site Kalaloch Beach and the south Roosevelt Beach close to the Quinault Indian Nation. Samples were taken from the whole intertidal range (about $50 \mathrm{ft}$ ) from high tide to low tide, with the majority collected at very low tide. About 30 juvenile clams (3-4 mo. old) and 30 adult clams (2-3 yr. old) were collected from Roosevelt Beach and Kalaloch Beach on July 12 and on July 15, 2015. Fresh razor clams were gathered using the traditional shovel method in the field, and then separated tissues from the shell before frozen and storage. A total of 123 samples (both juveniles and adults) were gathered for the project.

In the laboratory Pacific razor clam shells were cleaned with a 5\% bleach solution, and then rinsed with distilled water three times. After drying at room temperature, most periostracum skin of the shells was removed from the cleaning process. The clam shells were micro-sampled using the Dremel method [9]. All sampling was limited to the outer foliated calcite layer of the shells, and at least 50 micrograms of materials were extracted from the shell surface. Once a sample was taken, the powder was tapped onto aluminum foil and placed into a centrifuge tube. The shell sample and the sampling bit were subsequently cleaned using an Aero-Duster gas. 
Analysis of powder samples was performed in the Stable Isotope Laboratory of the University of Michigan Ann Arbor, using a Finnigan MAT Kiel preparation device that is coupled directly to the inlet of a Finnigan MAT 251 triple-collector gas-ratio mass spectrometer. All the measurements were reported in the standard $\delta$ notation $(\%): \delta^{18} \mathrm{O}=$ $\left\{\left[\left({ }^{18} \mathrm{O} /{ }^{16} \mathrm{O}\right)_{A} /\left({ }^{18} \mathrm{O} /{ }^{16} \mathrm{O}\right)_{S}\right]-1\right\} \times 1000$, for instance, where $A$ is shell sample and $S$ is standard (VPDB, Vienna Peedee belemnite). Calibration of isotopic enrichments to VPDB standard is based on daily analysis of NBS-19 (National Bureau of Standards) powdered carbonate and the analytical precision is better than $0.08 \%$ for both $\delta^{18} \mathrm{O}$ and $\delta^{13} \mathrm{C}$ values.

\section{Result and Discussion}

The $\delta^{13} \mathrm{C}$ values of Pacific razor clam shells ranged from -2.9 to $-0.3 \%$, whereas $\delta^{8} \mathrm{O}$ values of the same samples ranged from -2.2 to $+1.4 \%$. The Shapiro-Wilk tests for normality for both $\delta^{13} \mathrm{C}$ and $\delta^{18} \mathrm{O}[10]$ indicated that not all the isotopic datasets of razor clams were normally distributed $(P<0.10)$. However, the frequency histograms of razor clam shells for both Kalaloch Beach and Roosevelt Beach samples showed that a possible bi-modal distribution for $\delta^{13} \mathrm{C}$ in juvenile clams may exist.

Between the two sampling sites, the isotopic data of razor clam shells showed differences in range and the mean values. In particular, the juvenile clam shells from the two sites were clearly separated at the $\delta^{13} \mathrm{C}$ values of about $-1.6 \%$, whereas the adult clam shells could be separated at the $\delta^{18} \mathrm{O}$ values of about $0 \%$ [Figure 1]. The non-parametric Mann-Whitney test showed that $\delta^{18} \mathrm{O}$ values were significantly different between Kalaloch Beach and Roosevelt Beach for both juvenile and adult clams $(P<0.001)$, whereas the $\delta^{13} \mathrm{C}$ values were significantly different between the two sites for juveniles $(P<0.0001)$, but not for adults $(P=0.650)$.
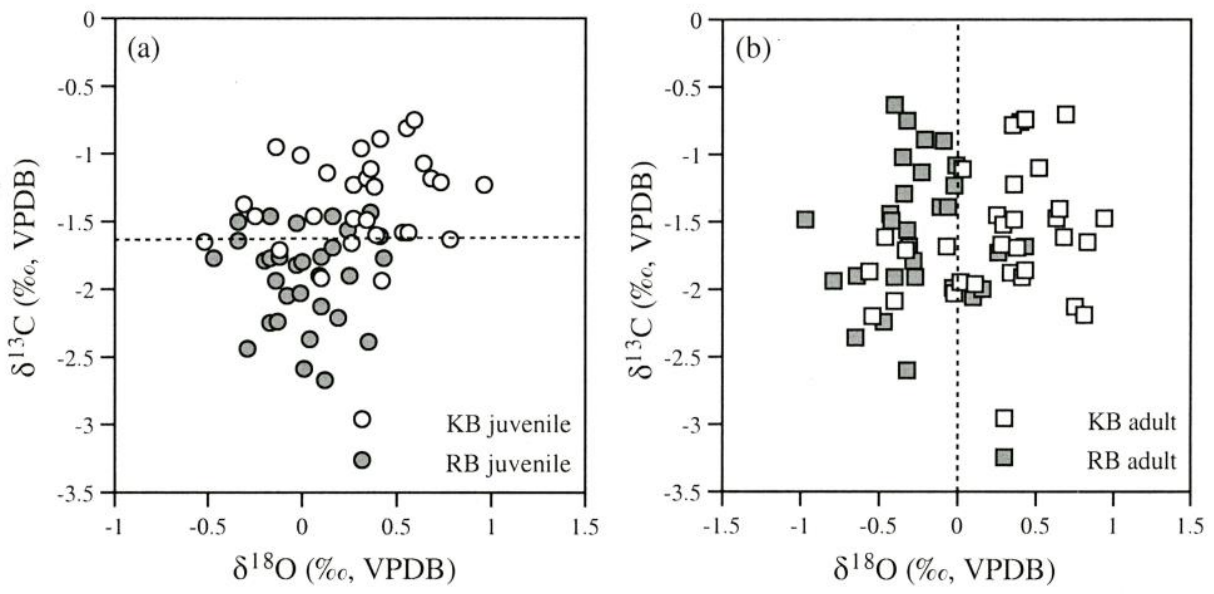

Fig. 1. The raw isotopic data comparison for juvenile (a) and adult clam shells (b) between Kalaloch Beach (KB) and Roosevelt Beach (RB).

These statistical results seem consistent with the raw data and frequency histograms. The depleted $\delta^{13} \mathrm{C}$ values in the Roosevelt Beach samples suggest juvenile clams may have more food [7] at that beach, which would be critical to the clam survival and early-stage growth. If the bi-modal distribution could provide evidence of the presence of more than one population or stock and the normality of the distributions as many methods of statistical analysis assume multivariate normality [10], the combination of shell morphology, raw 
isotopic data, and multi-statistics suggested there might be sub- spawning populations or stocks in coastal razor clams. For adult razor clams between the two sites, there were no significant differences in $\delta^{13} \mathrm{C}$ values $(P=0.650)$; nor apparent differences in adult shell morphology ( $t$-test, $P=0.64)$. The significant differences only in $\delta^{18} \mathrm{O}$ values $(P<0.0001)$ indicated that adult clams at Roosevelt Beach may experience a more favorable environment due to more freshwater mixing (i.e. more negative $\delta^{18} \mathrm{O}$ values). It is reported that the growth rates of razor clams are closely related to the prevailing ambient conditions and the predominant factor governing survival in the intertidal aquaculture is ambient temperature, due to the behavior of the clam to approach the sediment surface to feed [1]. We did not obtain temperature data from Roosevelt Beach during the study; however, it seems that the broader food sources in juvenile stage and more favorable beach conditions for the adults are the key elements for the higher growth and survival rates of the Roosevelt Beach clams.

From the $\delta^{18} \mathrm{O}$ profiles of two representative razor clam shells, we saw that the life-time $\delta^{18} \mathrm{O}$ variations showed seasonal patterns. These patterns indicate that $\delta^{18} \mathrm{O}$ of razor clam shells can be used as a proxy for generating a time series and detecting seasonal and annual environmental changes [4]. The life-time $\delta^{13} \mathrm{C}$ variations of the same Kalaloch Beach and Roosevelt Beach shells showed a peak at about age 1, and then a gradual decrease. The peak may indicate the highest period of metabolism in Pacific razor clam, or the age of maturity as interpreted in fish otoliths [8]. The Kalaloch Beach clam reached age 1 at 50 $\mathrm{mm}$, while the age 1 of the Roosevelt Beach clam was at about $57 \mathrm{~mm}$. The age at first maturity for the Kalaloch Beach clam was between ages 1 and 2, while the age of maturity of the Roosevelt Beach clam appeared before age 1 [Figure 2]. These growth details and differences may also provide evidence for our findings of possible sub-populations in razor clams.
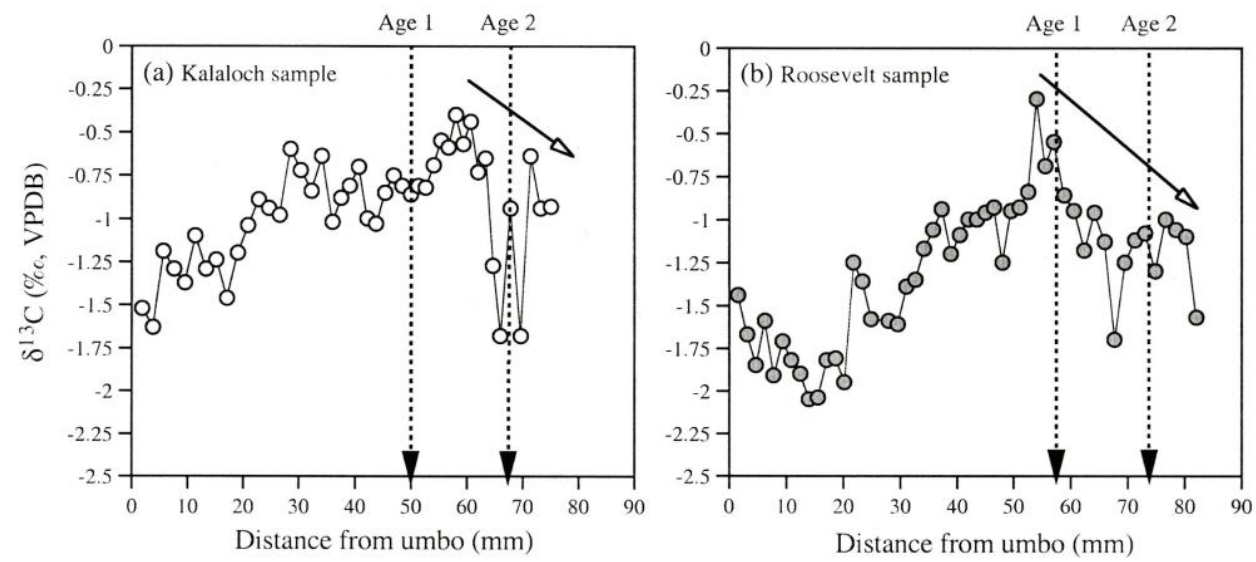

Fig. 2. Life-time ${ }_{-}^{-13} \mathrm{C}$ variations between the Kalaloch Beach and the Roosevelt Beach razor clam samples, showing a peak of ${ }_{-}^{-13} \mathrm{C}$ values at about age 1 (age of maturity) and reflection of normal growth or metabolism. The 'umbo' refers to the start part, or the oldest point of the valve in a shell.

After age of maturity, the $\delta 13 \mathrm{C}$ values of razor clam shells generally decrease [11]. A pattern of steady decrease of $\delta^{13} \mathrm{C}$ values throughout a calcifying organism's lifespan has been reported to be signatures of ocean acidification [12], because ocean acidification will lead to a shift in dissolved inorganic carbon equilibria and result in higher $\mathrm{CO}_{2}$ and lower carbonate ion $\left(\mathrm{CO}_{3}{ }^{2-}\right)$ concentrations. The changing of carbonate chemistry of the seawater will affect the ability of calcifying organisms to build protective shells and skeletons, a key effect on the razor clam production and recreational harvest. Although the life span of Pacific razor clam is short (only about 3 yrs. in this study), we did not observe a steady 
$\delta^{13} \mathrm{C}$ decrease in the $\delta^{13} \mathrm{C}$ profiles for ocean acidification [12]; instead, we obtained a common $\delta^{13} \mathrm{C}$ variation that may reflect the growth and metabolic effects.

\section{Conclusion}

We have demonstrated that stable carbon and oxygen isotope analyses can provide useful information about life history and growth of Pacific razor clams. Comparison between the Kalaloch Beach and the Roosevelt Beach samples revealed significant differences in juveniles that may result from the different food sources and supply, whereas the differences in adult clams may result from the different water conditions and sediments. These differences may be the major factors to explain the different growth and survival rates of razor clams between the Hoh Tribe traditional harvesting area and neighboring beaches. Carbon isotopic data from razor clam shells cannot be interpreted as effects of ocean acidification because of lacking of the pattern of a steady decrease in $\delta^{13} \mathrm{C}$ values.

\section{References}

1. D.R. Lassuy and D. Simons. Species Profile: life histories and environmental requirements of coastal fishes and invertebrates (Pacific Northwest) -Pacific razor clam. U.S. Department of Interior, Fish \& Wildlife Ser. Biol. Rep. 82 (1989)

2. WDFW (Washington Department of Fish and Wildlife). Razor clams (2016). Website: http://wdfw.wa.gov/fishing/shellfish/razorclams/

3. N.G. Adams, M. Lesoing and V. Trainer, J. Shellfish Res. 19, 1007-1015 (2000)

4. D.S. Jones, D. Williams, and M. Arthur, J. Exp. Mar. Biol. Ecol. 73, 225-242 (1983).

5. J.E. Fitch, Calif. Fish. Game Fish. Bull. 90 (1953).

6. C. Emiliani, Science 154, 851-857 (1966)

7. M.J. DeNiro and S. Epstein, Geochim. Cosmochim. Acta 42, 495-506 (1978)

8. H.P. Schwarcz, Y. Gao, S. Campana, D. Browne, M. Knyf, and U. Brand, Can. J. Fish. Aquat. Sci. 55, 1798-1806 (1998)

9. Y.W. Gao, Environ. Biol. Fish. 55, 443-448 (1999)

10. Y.W. Gao, R. Conrad, D. Bean, and D.L.G. Noakes, Environ. Biol. Fish. 96, 799-810 (2013)

11. D.E. Krantz, D. Williams, and D. Jones, Palaeogeog. Palaeoclim. Palaeoecol. 58, 249266 (1987)

12.Y.W. Gao, R. Svec, J. Morgan and D.L. Dettman, Appl. Geochem. 97, 256-262 (2018) 